\title{
LARGE DIAMETER SHALLOW AGRO-WELLS - A NATIONAL ASSET OR A BURDEN FOR THE NATION?
}

\author{
A. N. Jayakody ${ }^{1}$
}

\begin{abstract}
Large diameter open dug Agro-wells have become increasingly popular among farmers in the Dry and Intermediate Zones of Sri Lanka during the decades of 1980 and 1990. The numbers have expanded up to around 50,000 in an unprecedented manner as those were meant to serve as sources of water for irrigation of agricultural crops during the much drier Yala season as well as during the water stress times of the Maha season.

However, the haphazard expansion of Agro-wells has created complications after some time of use pertaining to the quantity and quality of available water. As Agrowells were constructed frequently by neglecting the appropriate technical norms, drying up of those have been experienced very often along with a lowering of the groundwater level in the respective areas. Moreover, the water in Agro-wells started to show increasing salt concentrations over the period of usage, which has affected the soils and crops detrimentally. As a result, farmers by now have abandoned a considerable number of Agro-wells, which were constructed by spending a significant amount of money.
\end{abstract}

As such, this paper describes the past and present scenarios of Agro-well farming in Sri Lanka considering the Agro-well net in the country as a national asset and attempts to suggest some possible trustworthy measures to be considered for efficient use and proper re-use of abandoned Agro-wells diverting away from the popularly accepted common paradigm "Agro-wells are only for irrigation of agricultural crops".

Key Words: Agro-wells, groundwater level, salt concentrations

\section{INTRODUCTION}

Inadequacy of water was and is one of the most prominent environmental constraints for agricultural cropping in the Dry and Intermediate Climatic Zones of Sri Lanka though the majority of soils of these Zones are at acceptable fertility levels. Hence, historically as well as during the past few decades, the agricultural cropping was practiced using either rainwater or water collected in village minor tanks and water diverted from the Wet Zone by major irrigation schemes. However, the amounts of naturally available water in the Zones along with the in- coming water from the Wet Zone seems to be incapable of feeding the command areas due to diminishing catchment areas, inefficient use of rainfall events as a result of improper timing of cultivation, high water losses, silting of village minor tanks and large reservoirs, poor water management etc. (Dharmasena, 1989). Along with the comprehensive aggravation of above, especially during the recent past, an additional and a higher attention has been given to look into the possibility extracting certain amounts of groundwater for cropping. Out of three common possibilities of 
tapping of groundwater namely deep bore-hole tube wells, small-diameter deep wells and large-diameter shallow wells (Agro-wells), the latter was found to be most suitable and appropriate and hence considered as an alternative source of water for the said Zones. Since around 1980, this type of wells was recognized commonly as Agro-wells by the farming community as well as by others in the country. The blessings as well as the assistance of the government and Non-governmental organizations as well were there to promote the blooming of Agro-wells in the Dry and Intermediate Zones because these were meant for irrigation of crops in Yala season and to supplement the water requirements in Maha season at times of water shortages. As such, the farmers got themselves directed to cultivate a variety of cash catching crops such as chili, onions, brinjals, guards, okra, long-bean etc. sometimes instead of paddy and specifically during Yala season as well. As much of the produce could be marketed more profitably, the Agro-well farming system was very enthusiastically accepted.

However, at present, the use of Agrowell water is not fulfilling the farmer's expectations and it appears that a considerable number of Agro-wells constructed during the past two decades were abandoned due to a diverse number of reasons converting those to be a "burden" to agricultural cropping.

Nevertheless, it has become a necessity of the time to pay a serious attention on proper re-use of those because the Agro-well-net in the country has to be considered as a very valuable national asset due to the fact that a large sum of money and labor were spent on the construction expecting to be a lifetime investment that need hardly maintenance compared to other irrigation constructions. Therefore, should not be the existing paradigm "Agro-wells are for irrigation of crops" be shifted towards a higher level of multiple use? Of course, the irrigation of crops could remain as the prime use. Hence, the time has reached to think of and suggest alternative ways and procedures in view of up-lifting the living standards of farmers in Agrowell environments capable of providing avenues of increased income.

Giving due attention to the said aspects, this paper attempts to discuss the significance and the nature pertaining to the past and the present of Agro-well in view of proposing future changes needed.

\section{DISCUSSIONS}

\section{Need for Agro-wells}

It is a well-established fact since thousands of years that the Dry and the Intermediate Zones of Sri Lanka is characterized by moisture stress when practicing agriculture. The large scale Mahaweli Diversion Irrigation Project could help this situation only partially. Though there were around 20,000 minor village tanks in these regions, only about $50 \%$ are in good operational conditions experiencing a gradual decrease of the capacity further (Udawattage, 1985, Kendaragama, 2000). There are also constraints such as decline of catchment forests, ineffective use of rainfall, improper water management, intensive cropping, increase of rural population, high tank evaporation losses etc. in using minor village tanks demanding supplementary water sources for comfortable existence. According to De Silva (2002), the major irrigation 
schemes could only supply water for about half of the croplands. The water shortages are specifically experienced during Yala season as well as during some periods of Maha season where life-serving irrigation is required without which the smooth and uninterrupted cropping be hampered. It is therefore thought that extraction of shallow groundwater by means of constructing large diameter Agro-wells would be able to supplement water irrespective of naturally occurring moisture depletions within a range of a low maintenance cost even though the initial capital investment would be comparatively high for an average farmer. Besides, these would have the potential to stabilize the farming life also by increasing the areas of cultivation which will not destruct the natural physical environment similar to the case of construction of irrigation canals as well as water storing and diverting devices. Agro-wells are considered to be life- time investments for which long-term government attention and assistance is not much needed for the maintenance. The usually listed other advantages are of having independent/private source of irrigation, suitability for isolated areas lacking facilities from central irrigation schemes, possibility of year around more or less uniform supply and water free from numerous contaminants such as weed seeds, suspended solids as well as harmful organisms etc.

However, the need of lifting waterusing pumps, initial capital and slightly anticipated deterioration of irrigation water quality were considered then as constraints but not as serious disadvantages. As the advantage-pan of the balance was so heavy, the government has also taken a decision to promote and support the expansion of Agro-wells in the region. In accordance with all above, there were evidences of significant increases of productivity and farmer income during the initial stages (Aheeyar and Ariyabandu, 2002). Hence, nobody thought that this endeavor could be hazardous in the long run basically due to unawareness of users about recharging potentials and alteration of water qualities. The prime parameter in the process of construction was the quantity of water to be used. The paradigm of growing "rice only" was to be changed at that time aiming at higher gains per unit area of land as well. Thus the farmers have started to grow more other field crops and vegetables using Agro-well water. Along with, they have also used this water for irrigation of paddy as well. The water of Agro-wells was used indiscriminately through procedures of flood irrigation, as water was available easily at hand. All in all, the Agro-well farming systems were thriving for a while making the farmers providing better returns.

\section{Expansion and Construction}

Prior to 1980s, Agro-wells were not much noticeable though there were some large diameter wells traditionally used for irrigation in Jaffna peninsula and the eastern province. Besides, little large diameter wells were observable in some school and hospital premises utilizing for drinking. However, a noticeable number of Agro-wells were constructed commencing from around 1980 especially in the districts of Kurunegala, Anuradhapura, Moneragala, and Hambantota. As estimated in 2000, the number of Agro-wells amounts to around 50,000 (Kikichi et al., 2002). More than 90\% of these are extracting water on hard rock aquifers (De Silva, 1994). The boom of Agro-wells in Sri Lanka accelerated as a result of a nationwide government intervention by providing 
a subsidy through the Agriculture Development Authority (ADA) of the then Ministry of Agriculture and Lands. The ADA has provided subsidies for construction of about 15,000 Agro-wells during a period of 10 years (Karunaratne, 2002). This action has leaded a numerous number of Non Governmental Organizations as well as able individual farmers to engage in Agro-well constructions. According to the reports of Kuruppuarachchi (1995) and Kendaragama (2002) there should be over 40,000 Agro-wells within the Dry and Intermediate Zones itself.

Construction of a borehole tube Agrowell has costed around Rs. 125,000/= in 1990 as against Rs. 30,000/= (without labor) for a large diameter Agro-well (Premaratne, 1994). Estimations of Wijesinghe and Kodituwakku (1900) includes a sum of Rs. $10,000 /=$ for pumping devices. In case of tube-wells, the pressure aquifers have to be met by drilling to a depth of 30 to $50 \mathrm{~m}$ using modern equipment. Such tube-wells meant for irrigation are plenty to be observed in Puttlam. Mannar, Mulletivu, Hambantota, Kalpitiya and Jaffna. However the share of these type is non-comparable with large diameter shallow Agro-wells.

Though there are proper technical instructions laid down/proposed to verify the water yield in Agro-wells before completion by running prior tests, many have ignored such perhaps due to the positive attitude of the government to support financially such constructions. Besides, the tools and the technique needed are very simple. For example, according to Premaratne (1994), there should have been only one well to serve about 34 acres of highland or 17 acres of lowland and Pieris (1990) stated the minimum distance between two wells as $300 \mathrm{~m}$. However, the ground situation is that in some locations there are few wells within $100 \mathrm{~m}$ distance even. As suggested by Pieris (1990) the initial step should have been to construct a small diameter (about $1.2 \mathrm{~m}$ ) test well and if only there appears a $1 \mathrm{~m}$ water column having a recharge rate of 100 $125 \mathrm{~L}$ per hour after digging the well up to a depth of $6 \mathrm{~m}$. If the above conditions are fulfilled only, the well should be enlarged to a diameter of 5 $\mathrm{m}$. However, the majority of constructions had been done without giving any kind of attention to the parameters mentioned. Private ownership and hence the individual decisions were dominating especially during the popularizing phase of 1990s.

With all the irregularities and negligences many Agro-wells have been constructed in command areas of village minor tanks expecting recharges by tank seepage and rain. Agro-wells were also constructed in command areas of large irrigation schemes as well, to which more water is been diverted from the Wet Zone. The general pattern of occurrence is about $80 \%$ in paddy tracks and the rest in relative uplands (Kuruppuarachchi, 1995). Dharmasena et al. (1993) developed an Agro-well Potential Estimation Model (APE) as a tool using investigations conducted in Mahakanumulla Cascade of Anudhapura District considering all aspects related to water in the location.

There are two types of Agro-wells pertaining to the approach of construction namely lined with bricks or cement blocks and unlined where the walls hard enough to retain without collapsing. The average dimensions and performances were listed in Pemaratne (1994) as having a diameter 
of $5.0 \mathrm{~m}$, a depth of 6.4 , a water level at $3.5 \mathrm{~m}$ below ground level with a fluctuation of $1.9-5.0 \mathrm{~m}$, and a pumping capacity of $27-45 \mathrm{~m}^{3}$ per hour.

The existing Agro-wells have to be considered as a national asset because the cost incurred for construction exceeds Rs. 30 mill. if the construction of an Agro-well would be estimated at Rs. 60,000/= without even considering the cost of labor. Hence this asset should be utilized for the benefit of the agricultural production through adopting well thought appropriate procedures while understanding the present constraints.

\section{The Dilemma at present}

There are some concerns at present in reference to Agro-wells in general. The most prominent negative indications are reduction of recharging up to even drying out at mid-season and the deterioration of water quality for irrigation purposes related to salt concentrations which in turn has a potential to increase the salinity of the soils in time to come. In fact, there are already indications about increase of salinities in soils (Cooray, 2002). It is estimated that around $30 \%$ of Agrowells have been abandoned due to one or/and the other mentioned above and many are in the pipeline of recent abandoning.

In regard to decreasing yields of water, one could perhaps think about water saving management procedures if the quality of water is acceptable for irrigation. If the quality were not suitable, even overcharging would be of no use. There are in fact Agro-wells abandoned though there are enough quantities of water therein. In view of making this national asset, the Ministry of Agriculture has launched an Agrowell linked micro-irrigation package since 1997 by providing subsidies and establishing loan schemes to farmers to achieve a drastic reduction of water extraction as for the sustainability, the amount of water extracted should be lesser than the recharge on an individual Agro-well.

There are also observations related to overall reduction of groundwater reservoirs signaled by lowering of the depths of water tables at certain locations (Premaratne, 1994). Numerous conflicts especially between neighbouring farmers have been frequently observed at instances with regards to the influence of water extraction of one Agro-well on another coupled with the farming system and the extent cultivated. In such situations, deepening of wells have been undertaken which in turn lowered the water levels of small diameter deep drinking wells aggravating the conflict situations. Besides, extended dry spells in the medium and small streams of the near vicinity were also experienced. There are reports from Tamil Nadu in India stressing about permanent depletion of groundwater resources as a result of expansion of the Agro-well net and indiscriminate extractions of water. Thus, the abandoning of Agrowells has become a common seen at present. Abandoning due to shortage of recharge is observed mostly in the Agro-wells located at comparatively upper elevations hampering especially the cultivation of other field crops and some vegetables which aught to bring higher incomes to farmers. Hence, the abandoning of Agro-wells has become a signal of the reduction of farmer income depleting the quality of once elevated living standard.

Though there are a dearth of quantitative data and scientific 
interpretations on drying out of wells and lowering of groundwater tables, there are a plenty of information available on quality of Agro-well water related to situations in Anuradhapura district, which could be considered as representative. Most of the studies were conducted to investigate the salt levels interpreted using Electrical Conductivity (EC) as the prime tool. As there are a lot of abandoned Agrowells to be seen with ample amounts of water in those, it is fair to be concluded that these have bad quality water for irrigation of crops.

Investigations conducted by Kendaragama (2000) in Paindikulam of Anuradhapura district reviled that the salinity levels of water in village minor tanks as well as water drawn from large tanks are very much lower than that of Agro-well water emphasizing the loading of salts to water while passing through the soil body perhaps mainly originated from added fertilizers and manure during cropping cycles. Out of 17 Agro-wells studied, around $80 \%$ had highly saline water that cannot be recommended as safe. Besides the danger of loading the soils with salts from such water has been reported therein giving special emphasis to sodium that could also disperse the flocculated soil colloids leading to structural deteriorations. Dharmasena et al. (1993) reported about average EC levels of village minor tanks in the same area as 0.29 $\mathrm{dS} / \mathrm{m}$ and of Agro-wells as $1.3 \mathrm{dS} / \mathrm{m}$, which represents also a high salinity level according to Ayers and Wescot (1985). The $\mathrm{pH}$ ranges of water were also observed to be in the alkaline range of 7.6 to 8.4 mainly in poorly drained locations, which could also be not accepted as good quality irrigation water. Based on a study conducted by Perera (2002) drawing 97 Agro-wells for sampling, around 50\% of Agro- wells showed high salinity levels. Only about $10 \%$ had good quality water. All of these results indicate about increased salinities so that water has become not suitable for cropping. As farmers have experienced negative outcomes justifiably, they have abandoned the Agro-wells though they do not have any idea about salinity as the reason. The data received through an in-depth study by selecting in-use and abandoned Agro-wells under the supervision of the author of the paper as well Cooray (2002) had reported almost similar phenomena. The studied parameters such as $\mathrm{pH}, \mathrm{EC}$, concentration of $\mathrm{Na}, \mathrm{K}, \mathrm{Ca}$, and $\mathrm{Mg}$, and the SAR indicated contrasting differences among village minor tank water, Agro-well water in use and water in abandoned Agro-wells. Lowest values for all parameters were found in village minor tank water except for $\mathrm{K}$ where the water could be considered as acceptable. However both in-use as well as abandoned Agro-wells unsuitable water qualities were the general picture to be observed. The investigation locking into soil also showed a little loading of salts, which may increase in time to come if the operations remain similar. This could perhaps lead to abandoning of land from cropping as well because there is a potential of increase of soil salinity in future. Hence to consider this level of Agro-well farming as a burden would be justified as soils, water plants as well as the entire environment could be badly affected.

In overall context some even consider the Agro-well system as an unsuccessful agricultural endeavor as water is used only for cropping. 


\section{SUGGESTIONS FOR FUTURE USE AND RE-USE}

In view of increasing the agricultural income of the farmer community associated with Agro-well environments, it is an invariable requirement to improve the water uses efficiency in the first instance so that the quantities of water extraction from Agro-wells are substantially reduced over the coming seasons. A kind of a multipurpose utilization package has to be thought of as an immediate measure to bring this national asset out of the burden scenario.

Premaratna et al. (1994) recommends the following as suitable activities to regularize the proper use of Agro-wells and convert the users to be more responsible. In his view the subsidies have to be frozen and register the details of the Agro-well users including technical data on the wells so that a licensing could be launched while stressing the importance of education the farmers on exploitation rates and optimal use of water. At a Symposium held on "The use of Groundwater for Agriculture in Sri Lanka" on $30^{\text {th }}$ September 2002 at the Post Graduate Institute of Agriculture, University of Peradeniya organized by the Agricultural Engineering Society of Sri Lanka; some policy guidelines have been proposed. Among those, conjunctive use of Agro-well water with rainfall and tank water, control of number of wells in operation, educate politicians, public officers, NGOs and farmers, bringing into act of new legislation and introduction of suitable cropping systems were the main features.

However, it would be most appropriate initially to establish a rapport between representative Agro-well farmer communities and the knowledgeable in the field to understand well there present grievances and requirements. Blending of farmer perspectives with the following suggestions as well would be worthy to consider even with launching pre-testing and verifications in situations of need.

1. The farmers should be enlightened with the Agro-well associated cropping by emphasizing the advantages and disadvantages of Agro-well farming considering that the Agro-wells are not just another type of wells.

2. Provide useful information to farmer community pertaining to soils, crop selection, crop layouts, fertilizer, manure and agrochemical use, efficient and safe irrigation procedures etc.

3. Motivate farmers to go for water saving irrigation techniques such as efficient use of rainfall, avoidance of flood irrigation and introduction of micro-irrigation though it would be costly.

4. While injecting an attitude that Agro-wells are not only for irrigation, ornamental or other fish farming could be introduced to Agro-wells as an additional source of income by giving due recognition and respect to social, cultural and religious principles. In this endeavor, breeding and growing of aquarium/aquatic plants could also be linked subsequent to pre-testing and investigations on marketing channels. This would also contribute to reduce the levels of numerous salt ions converting the water as suitable for reducing the potential of 
soil salinity build up. A kind of a floating cage system could be adopted in rearing fish and aquatic plants for easiness of harvesting. Besides, this intervention would destroy mosquito larvae in Agro-wells as well.

5. A considerable amount of plant litter/debris are available just drying in each and every field due $\mathrm{t}$ non contact with water, the establishment of compost units to Agro-wells would be an additional advantage to fertility improvement of soils that could also improve the buffering of $\mathrm{pH}$ as well as other ions. If the farmer organizations become so keen, the compost so produced could be marketed after well packing. Use in the own field is however better.

6. It would be appropriate to motivate the farmers also to convert a small allotment of their land to a mini-orchard /mixed garden to enrich the ecology of the environment for which Agro-well water could be systematically used. Emphasis should be given to introduce perennials producing marketable products such as fruits and nuts which would bring the farmers a year around uniform income though could be also little.
7. Introduction of selected salt tolerant medicinal plants having high demands in the market as well for local Aurvedic Industry would be beneficial as a lot is imported especially from India.

8. Seek to crop possible salt tolerant varieties for the time being including scientifically to the cropping systems.

Hence the proper re-use of Agro-wells should be a duty of the government to give due attention to the present situation and seek to launch improvements through the participation of Provincial Councils, Research and Educational Institutions, Non Governmental Organizations and interested individuals etc. Though the present use looks like a burden, the situation should be rectified considering the physical structures available as a national asset.

\section{ACKNOWLEDGEMENTS}

The author wishes to express his gratitude to the Editor in Chief of the Journal of Agriculture Sciences of the Sabaragamuwa University, Prof. Rohana P. Mahaliyanaarachchi for inviting to present a paper on the occation of the $10^{\text {th }}$ Anniversary of the Sabaragamuwa University of Sri Lanka.

\section{References}

Aheeyar, M.M.M. and R. de S. Ariyabandu (2002). Socio-economic issue pertinent to Agro-well farming in Sri Lanka: Symposium Abstracts on The use of groundwater for agriculture in Sri Lanka, Agricultural Engineering Society of Sri Lanka/Post Graduate Institute of Agriculture, University of Peradeniya, Sri Lanka, 12 
Ayers, R.S. and D.W. Wescot (1985). Water quality for Agriculture, Irrigation and Drainage: Paper No. 29 (Rev.. 1)FAO, Roam, pp 174

Cooray, H.M.P., (2001). Impact of land use on fertility status of RBE-soils under rainfed and Agro-well farming: Project Report submitted for the B.Sc. (Agric.) Degree, Department of Soil Science, Faculty of University of Peradeniya, Sri Lanka, pp 68

De Silva C.S., (1994). Use of Agro-wells for supplementary irrigation from hard rock aquifers in Sri Lanka: Institute of Water and Environment, http://www.silsoe.cranfield.ac.ul/iwe/students/cdesilva.htm

De Silva, C.S., (2002). Regulation of shallow groundwater resources in hard rock areas of Sri Lanka: Symposium Abstracts on The use of groundwater for agriculture in Sri Lanka, Agricultural Engineering Society of Sri Lanka/Post Graduate Institute of Agriculture, University of Peradeniya, Sri Lanka, 6

Dharmasena, P.B., (1989). Optimum utilization of the storage in village tanks: Tropical Agriculturist, 145, 1-9

Dharmasena P.B., K.M.A. Kendaragama., R.M.B. Ranaweera and S.N. Jayasena., (1993). A field survey to provide guidelines for Agro-well farming in North Central Province of Sri Lanka: Research Terminal Report, CARP Project No. 12/93/75, Regional Agricultural Research Center, Mahailluppallama, Sri Lanka, pp 1-15

Karunaratne, A.D.M., (2002). Groundwater development through introduction of Agro-wells and micro-irrigation in Sri Lanka: Symposium Abstracts on The use of groundwater for agriculture in Sri Lanka, Agricultural Engineering Society of Sri Lanka/Post Graduate Institute of Agriculture, University of Peradeniya, Sri Lanka, 2.

Kendaragama K.M.A., (1997). Salinity status of water in Agro-wells in irrigated areas in the Dry Zone: Krushi, 16(2-3), 1-3

Kendaragama. K.M.A., (2000). Water quality of Agro-wells in the Dry Zone: A case study in Anuradhapura District, J.Soil.Sc.Soc. Sri Lanka, 12, 36 - 33

Kikichi, M., P.Weligamage., R. Baker., M. Samad., M. Kono and H.M. Somaratne., (2002). Agro-wells and pump in irrigation schemes in Dry Zone of Sri Lanka: Symposium Abstracts on The use of groundwater for agriculture in Sri Lanka, Agricultural Engineering Society of Sri Lanka/Post Graduate Institute of Agriculture, University of Peradeniya, Sri Lanka, 8

Kuruppuarachchi, D.S.P., (1995). Impact of irrigated agriculture on groundwater resource of Sri Lnaka: Proc. SLAAS, 51(2), 49-59

Perera. A.P.G.R.L., D.V.K. Wijekoon and A.A.A.K. Seneviratne., (2002). Water quality of Agro-wells in Anuradhapura district: Symposium Abstracts on The use of groundwater for agriculture in Sri Lanka, Agricultural Engineering Society of Sri Lanka/Post Graduate Institute of Agriculture, University of Peradeniya, Sri Lanka.

Peris, R.T.C., (1990). Stabilization of farming through Agro-wells in the Dry Zone of Sri Lanka: Symposium Proceedings of Irrigation and Water Resources, ODAUK, PGIA-University of Peradeniya and Agricultural Engineering Society of Sri Lanka, 192-198.

Premaratne, K.L.L. and T. Liyanapatabendi., (1994). Groundwater depletion due to Agro-wells: $20^{\text {th }}$ WEDC Conference, Affordable Water Supply and Sanitation, Plenary Session, Colombo, Sri Lanka, 11-13.

Udawattage, U.D.S. (1985). The development of micro-catchments in Sri Lanka: J. Hydrol., 80, $351-359$ 
Wijesinghe, M.W.P. and K.A.W. Kodituwakku, 1990. Agro-well systems to harness available groundwater resources for small scale farming: Proceedings of the Symposium on Irrigation and Water Resources, ODA-UK, PGIA-University of Peradeniya and Agricultural Engineering Society of Sri Lanka, 178 - 191 